\title{
The Application of Nanobody in CAR-T Therapy
}

\author{
Chaolemeng Bao ${ }^{1}$, Quanli Gao ${ }^{2}$, Lin-Lin Li ${ }^{2,3}$, Lu Han ${ }^{2}$, Bingxiang Zhang ${ }^{1}$, Yijin Ding ${ }^{1}$, Zongpei Song ${ }^{1}$, \\ Ruining Zhang ${ }^{1}$, Jishuai Zhang ${ }^{1}$ and Xian-Hui $\mathrm{Wu}^{1, *}$
}

1 Shenzhen Pregene Biopharma Company Ltd., Shenzhen 518118, China; baoclm@pregene.com (C.B.); zhangbx@pregene.com (B.Z.); dingyj@pregene.com (Y.D.); songzp@pregene.com (Z.S.); zhangrn@pregene.com (R.Z.); zhangjs@pregene.com (J.Z.)

2 Department of Immunology, Affiliated Cancer Hospital of Zhengzhou University and Henan Cancer Hospital, Zhengzhou 450008, China; zlyygq10855@zzu.edu.cn (Q.G.); LIN15838169920@163.com (L.-L.L.); zlyyhl2407@zzu.edu.cn (L.H.)

3 Department of Immunology, School of Basic Medical Sciences, Xinxiang Medical University, Xinxiang 453000, China

* Correspondence: wuxh@pregene.com

Citation: Bao, C.; Gao, Q.; Li, L.-L.; Han, L.; Zhang, B.; Ding, Y.; Song, Z.; Zhang, R.; Zhang, J.; Wu, X.-H. The Application of Nanobody in CAR-T Therapy. Biomolecules 2021, 11, 238. https://doi.org/10.3390/

biom11020238

Academic Editor: Nick Devoogdt

Received: 5 December 2020

Accepted: 1 February 2021

Published: 8 February 2021

Publisher's Note: MDPI stays neutral with regard to jurisdictional claims in published maps and institutional affiliations.

Copyright: (c) 2021 by the authors. Licensee MDPI, Basel, Switzerland. This article is an open access article distributed under the terms and conditions of the Creative Commons Attribution (CC BY) license (https:// creativecommons.org/licenses/by/ $4.0 /)$.

\begin{abstract}
Chimeric antigen receptor (CAR) T therapy represents a form of immune cellular therapy with clinical efficacy and a specific target. A typical chimeric antigen receptor (CAR) construct consists of an antigen binding domain, a transmembrane domain, and a cytoplasmic domain. Nanobodies have been widely applied as the antigen binding domain of CAR-T due to their small size, optimal stability, high affinity, and manufacturing feasibility. The nanobody-based CAR structure has shown a proven function in more than ten different tumor-specific targets. After being transduced in Jurkat cells, natural killer cells, or primary T cells, the resulting nanobody-based CAR-T or CAR-NK cells demonstrate anti-tumor effects both in vitro and in vivo. Interestingly, anti-BCMA CAR-T modulated by a single nanobody or bi-valent nanobody displays comparable clinical effects with that of singlechain variable fragment (scFv)-modulated CAR-T. The application of nanobodies in CAR-T therapy has been well demonstrated from bench to bedside and displays great potential in forming advanced CAR-T for more challenging tasks.
\end{abstract}

Keywords: nanobody; $\mathrm{V}_{\mathrm{H}} \mathrm{H}$; CAR-T; BCMA

\section{Introduction}

Cell therapies encompass a vast number of agents in immuno-oncology development [1]. In various types of cell therapy, the chimeric antigen receptor (CAR) T cell is the most dominant and active anti-tumor agent in the treatment of cancers, especially in hematological malignancies [2], while limited activity has been shown in solid tumors and several challenges need to be overcome regarding its application [3]. The CAR structure is a genetically engineered molecule that direct $\mathrm{T}$ cells to specifically attack tumor cells through an antibody-antigen interaction rather than in a major histocompatibility complex (MHC)-dependent manner. Three CAR-T cell-based therapies, tisagenlecleucel (Kymriah), axicabtagene ciloleucel (Yescarta), and brexucabtagene autoleucel (Tecartus), have so far been approved by major regulatory agencies on B-cell precursor acute lymphoblastic leukemia (B-ALL) - that is refractory or in second or later relapse [4], $\mathrm{r} / \mathrm{r}$ large B-cell lymphoma [5], and $\mathrm{r} / \mathrm{r}$ Mantle-Cell Lymphoma [6]. All three CAR-T therapies target overexpressed CD19 membrane proteins.

\section{Brief History of CAR T Cell Development}

The antitumor potential of $\mathrm{T}$ cells was realized about fifty years ago. It involved three stages, as shown in Figure 1A. It started from undefined targets/clinically effective cytotoxic T lymphocytes (CTLs) and tumor infiltrating lymphocytes (TILs) therapies, evolved into target-specific but clinically ineffective T-body and 1st generation CAR-T, and 
eventually became target-specific and clinically effective CAR-T therapies. In the 1970s, cytotoxic T lymphocytes (CTLs) were initially discovered to kill a variety of tumor cells, including P815 mastocytoma cells and EL4 lymphoma cells [7,8]. These reports reveal the potential application of $\mathrm{T}$ lymphocytes in cancer therapy. Tumor infiltrating lymphocytes (TILs) harvested from human dissected tumor tissues formed a straightforward application. These TILs were cultured ex vivo for four to eight weeks [9] and then re-administered intravenously along with a dose of IL-2 [10]. The clinical treatment exhibited encouraging effects on the regression of metastatic melanoma in $60 \%$ of patients enrolled [11]. The autologous CTLs and TILs are effective as therapeutics upon multiple undefined targets. Variable neo-antigens have been developed to simultaneously stimulate $\mathrm{T}$ cells for the treatment of solid tumors, and these are believed to achieve better clinical outcomes by overcoming the tumor heterogeneity [12]. However, their routine application still encounters challenges in manufacturing and prohibitive cost [13].

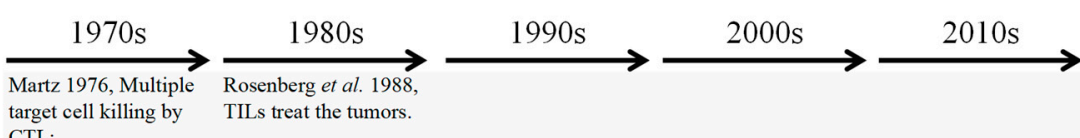

Clinically Effective
Defined Targets
Clinically Ineffective

CTL;
Rothstein et al. 1978 ,

CTLs kill various

tumor cells.

Defined Targets

Clinically Effective

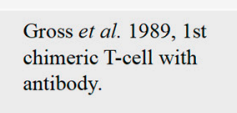

antibody.

Clinically Ineffective

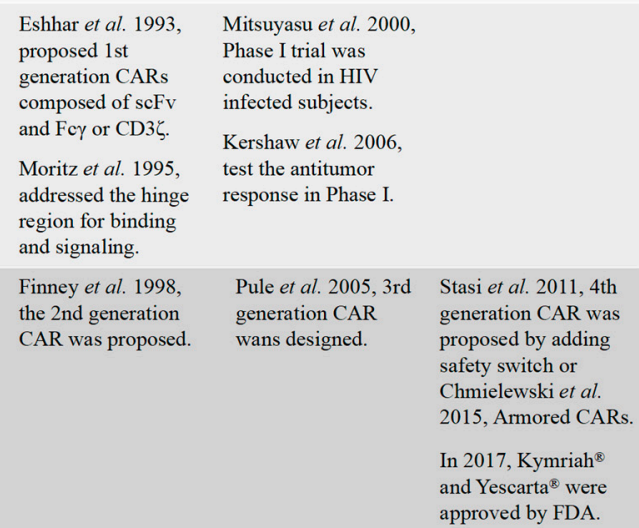

(A)

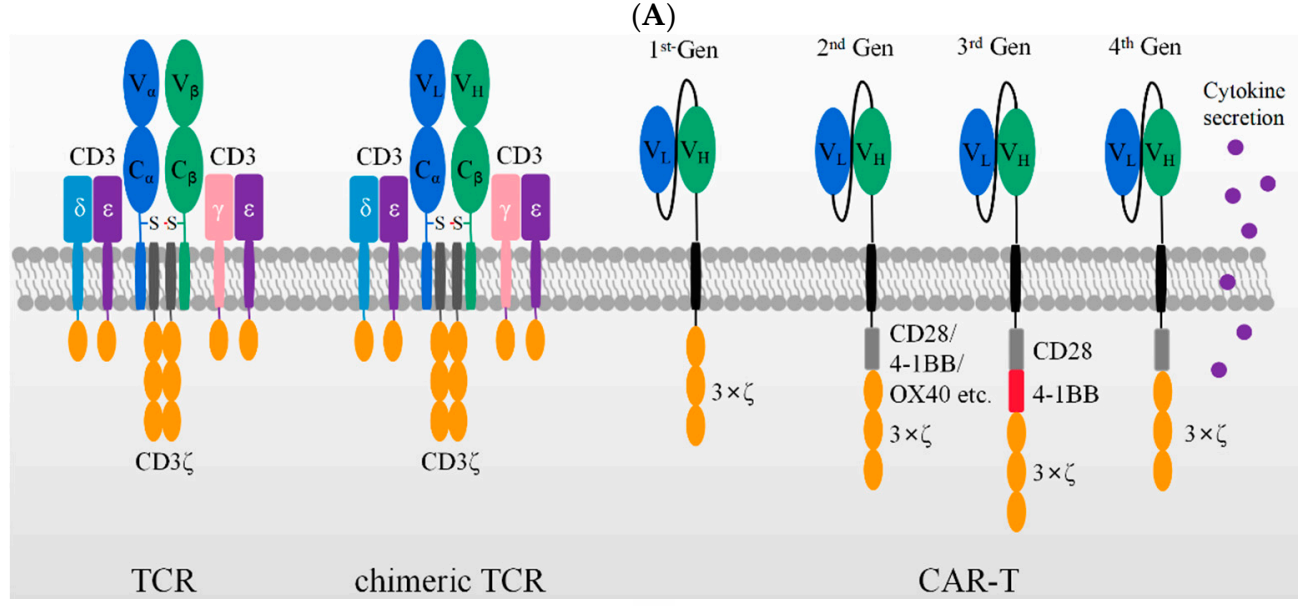

(B)

Figure 1. A brief history of cellular immunotherapy development from bench to bedside. (A) The CAR-T therapies evolved from undefined targets/clinically effective, defined targets/clinically ineffective, to defined targets/clinically effective. (B) The schematic figures of TCR machinery, chimeric TCR machinery, and different generations of CAR-T with the use of $\mathrm{scFv}$.

Target-specific $\mathrm{T}$ cells with chimeric receptors were firstly proposed by Zelig Eshhar and Gideon Gross in 1989 [14]. The $V_{\alpha}$ and $V_{\beta}$ domain of $\alpha \beta$ - T-cell receptor (TCR) were substituted by $\mathrm{V}_{\mathrm{H}}$ and $\mathrm{V}_{\mathrm{L}}$ of an anti-2,4,6-trinitrophenol (TNP) antibody, respectively. The 
resultant construct generated an artificial and chimeric TCR in the form of either $\mathrm{V}_{\mathrm{H}^{-}}-\mathrm{C}_{\alpha} / \mathrm{V}_{\mathrm{L}}-$ $\mathrm{C}_{\beta}$ or $\mathrm{V}_{\mathrm{L}}-\mathrm{C}_{\alpha} / \mathrm{V}_{\mathrm{H}}-\mathrm{C}_{\beta}$, as shown in Figure $1 \mathrm{~B}$. The engineered receptor was a chimeric TCR, which is capable of binding TNP-coated target cells and activating cell lysis through the TCR machinery in an MHC-independent manner. As shown in Figure 1B, the first generation of CAR was designed by adjoining the scFv of the TNP antibody, a transmembrane domain, and the cytoplasmic immunoreceptor tyrosine-based activation motif (ITAM) domain of the CD3k or immunoglobulin Fc receptor $\gamma$-chain. T cells expressing such a genetically engineered first-generation CAR construct were also named T-body [15]. Although they could specifically kill the targeted tumor cells in vitro and in vivo in mouse models, these first-generation CAR-T cells showed a low cytotoxicity $[16,17]$ and lacked the ability of long persistence in vivo [18]. Thus, they were not yet clinically effective.

The inability of long-lasting circulation in vivo was rapidly realized to be caused by the lack of the essential costimulatory receptor, as tumor cells rarely express a costimulatory receptor ligand such as B7 [19]. Therefore, in the second-generation CAR a cytoplasmic signaling domain from a costimulatory receptor, such as CD28 [20], 4-1BB [21]. or OX40 [22], was deliberately inserted between the transmembrane sequence and the ITAM domain of CD3 $\xi$. These constructs display an optimized $T$ cell activation, increased antigen-dependent proliferation in vitro [23], enhanced in vivo persistence, and more effective anti-tumor activity $[24,25]$. The second-generation CARs with a CD28 or 4-1BB costimulatory domain are currently well-established and the three FDA-approved anti-CD19 CAR-T cells are based on such constructs [4-6].

To further increase the $\mathrm{T}$ cell activation, a third-generation CAR was developed by incorporating an additional co-stimulatory domain into the second-generation CAR. Their typical

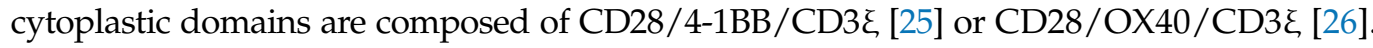

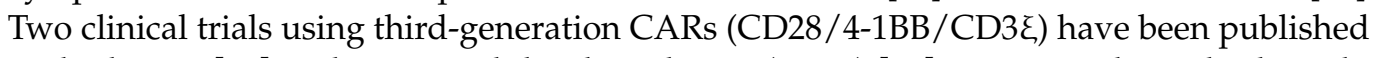
on leukemia [27] and Non-Hodgkin lymphoma (NHL) [28], respectively. In both trials, the CAR-T cells transduced with third-generation CARs reveal a superior expansion and longer persistence, particularly in patients with a low disease burden and low levels of normal B cells [28]. Nonetheless, the number of patients treated by third-generation CAR-T is not large enough to lead to a conclusion.

Although clinical trials show the persistent efficacy of CAR-T in treating hematologic malignancies, the treatment of solid tumors has encountered major challenges. Solid tumors impede the efficient penetration of $\mathrm{T}$ cells and demonstrate a hostile micro-environment, which limits the effective cytotoxicity from CAR-T to the target tumor cells $[29,30]$. Therefore, the efficacy of CAR-T in solid tumors seems to depend on its enhanced cytotoxicity, longer persistence, and modulation of the tumor microenvironment by secreting cytokines simultaneously. The fourth-generation CARs were designed by adding new functions beyond $\mathrm{T}$ cell activation signals, including the secretion of a variety of cytokines and extra antibodies [31]. In particular, co-expressed cytokines and antibodies are believed to modulate the immune microenvironment within the solid tumor tissues. Such T-cells redirected for antigen-unrestricted cytokine-initiated killing (TRUCKs) combine the direct antitumor attack of CAR-T cells with the immune-modulating capacities of the delivered cytokines, including IL-7, IL-12, IL-15, IL-18, IL-23, and combinations thereof [31]. In addition, the CAR-T cell-directed release of these proteins ensures their local release to the targeted tumors and avoid the risky adverse events that can potentially be caused by systemic administration.

For instance, the systemic administration of IL12 is highly toxic, thus limiting its clinic application at therapeutically effective doses [32]. IL-12 is majorly responsible for the induction and enhancement of cell-mediated immunity. Its capabilities include activating the cytotoxicity of natural killer (NK) and T cells by inducing INF- $\gamma$ release, inhibiting and reprogramming immunosuppressive cells, and upgrading the expression of MHC $[33,34]$. The local release of IL12 with the use of CAR-T cells is suggested to strongly modify the tumor microenvironment by avoiding the toxicity of systematic administration $[35,36]$.

CD19 CAR-T cells maintain a less differentiated phenotype and improve metabolic fitness, as has been seen ex vivo in the presence of IL15, which results in superior in vivo 
antitumor activity [37]. In this case, IL15 is suggested to be a promising application in armored CAR-T cells.

IL18 is a proinflammatory cytokine that belongs to the IL-1 cytokine family. It plays a role in inducing INF- $\gamma$ release with the use of IL12 or IL-15. This property makes IL-18 a promising candidate for enhancing the anti-tumor efficacy of genetically modified $\mathrm{T}$ cells. IL18-secreting CAR-T cells exhibit their enhanced expansion, persistence in vivo, and enhanced antitumor activity in xenograft models [38,39].

Besides CAR-T therapy, TCR-T therapy also modifies the patient's own T lymphocytes ex vivo but also applies T cell receptors (TCRs) [40]. TCR is a heterodimeric membrane protein composed of $\alpha$ - and $\beta$-chains. Antigen recognition by $\alpha \beta$-TCR depends on HLA, which presents intracellular peptide fragments. Thus, TCR-T cell therapy has a wider range of targets. However, TCR-T cell therapy is HLA-restricted not only in its presentation but also in its activate $\mathrm{T}$ cell function [13].

\section{The Antigen Binding Domain of CARs}

Thus far, the market has authorized three CAR-T cell products that all target CD19 and rely on $\mathrm{scFv}$ derived from the same murine monoclonal antibody, FMC63. The variable heavy-chain $\mathrm{V}_{\mathrm{H}}$ and light-chain $\mathrm{V}_{\mathrm{L}}$ are linked by a (GGGGS) ${ }_{3}$ sequence, and the resulting $\mathrm{scFv}$ fulfills the role of antigen binding. The scFv is a widely accepted format to develop both CAR-T therapies and bispecific antibodies due to its compact size, high affinity, and specificity maintenance in antigen recognition [41]. However, the form of scFv may partially compromise its antigen binding capacity and stability. Compared with $\mathrm{Fab}, \mathrm{V}_{\mathrm{H}}$ and $\mathrm{V}_{\mathrm{L}}$ in scFv lack stabilization elements/structure through the constant domains of $\mathrm{CH}_{1}$ and $\mathrm{C}_{\mathrm{L}}$. Meanwhile, the hydrophobic patches separating from the constant domains are exposed and need further engineering [42].

In addition to the antigen binding capacity and stability, the structure of $\mathrm{scFv}$ may also give rise to other potential risks and challenges in its application. A compatible linker sequence is required to connect $\mathrm{V}_{\mathrm{H}}$ and $\mathrm{V}_{\mathrm{L}}$ [43], and the linker sequence as well as the murine framework are the origin of immunogenicity risks that may lead to the generation of anti-drug antibodies (ADA) in vivo. The ADA effect could neutralize CAR-T cells' functions and cause serious side effects, CAR-T cell loss, and even the failure of CAR-T therapy $[44,45]$. In ex vivo expansion, T cell exhaustion typically occurs due to CAR aggregation in an antigen-independent manner [44,46,47], which is probably triggered by the variable domains of scFv, as shown in Figure 2 [46]. This is consistent with previous reports that scFvs have a high propensity for self-aggregation because the hydrophobic patches are exposed on variable domains after deleting constant domains [42,47].

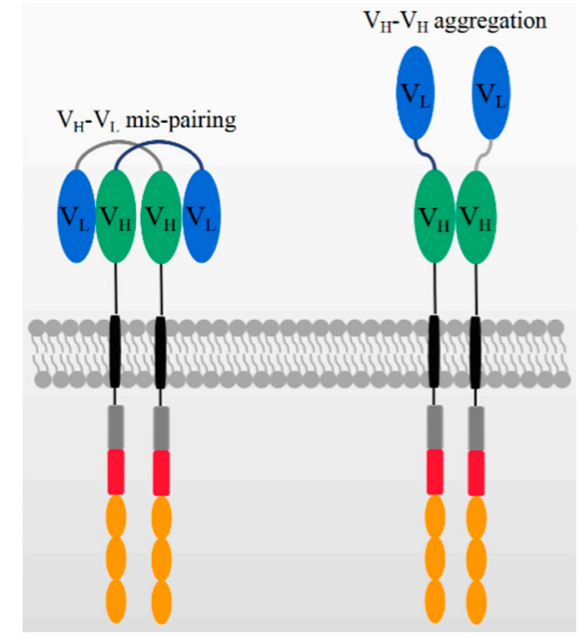

Figure 2. The mechanism of potential $\mathrm{V}_{\mathrm{H}}-\mathrm{V}_{\mathrm{L}}$ mispairing and $\mathrm{V}_{\mathrm{H}}-\mathrm{V}_{\mathrm{H}}$ aggregation on high CAR expression levels. 
On the other hand, the structure of $\mathrm{scFv}$ may limit its potential for constructing more complicated CAR structures. Generally, bi-specific CARs can be constructed from two tandem antigen binding domains, referred to as TanCAR, which can recognize two different antigens or one/two epitopes on one antigen. In constructing TanCARs, the potential crosspairing of $\mathrm{V}_{\mathrm{H}}$ and $\mathrm{V}_{\mathrm{L}}$ among two independent $\mathrm{scFv}$ molecules results in affinity loss [48]. In addition, multiple scFvs may influence the manufacturing because the size of the inserted gene compromises the viral packaging efficiency [49-51]. As shown in Figure 2, the over expression of CAR genes can result in the dynamic swapping of $\mathrm{V}_{\mathrm{H}}-\mathrm{V}_{\mathrm{L}}$ domains between different CAR units and aggregation on the cell surface. ScFv aggregation or misfolding could be caused by low folding stabilities of the $\mathrm{V}_{\mathrm{H}}$ or $\mathrm{V}_{\mathrm{L}}$ domain or the exposure of hydrophobic residues at the $\mathrm{V}_{\mathrm{H}}-\mathrm{V}_{\mathrm{L}}$ interface [52,53]. The aggregation of CARs may induce excessive cytotoxic signaling independent of tumor antigens and eventually cause the early exhaustion of T cells [54].

As an alternative to $\mathrm{scFv}$, using nanobodies in CAR-T constructs may attenuate the above-mentioned disadvantages. The nanobody, also called $\mathrm{V}_{\mathrm{H}} \mathrm{H}$ antibody, is derived from the variable domain of heavy chain-only antibodies (HcAbs). The natural existence of functional heavy chain-only antibodies was found firstly in dromedaries by HamersCastermans et al. in 1993 [55] and has been widely found in Camelidae [56] and sharks [57] since then. The antigen recognition site of the HcAbs is the variable domain of the heavy chain of the $\mathrm{HcAbs}$, referred to as $\mathrm{V}_{\mathrm{H}} \mathrm{H}$. Although a nanobody binds to the antigen in the complete absence of a $\mathrm{V}_{\mathrm{L}}$ domain and constant domain, the binding capacity, specificity, solubility, and stability are comparable with those of traditional antibodies [56]. In addition, nanobodies are often composed of a long CDR3 sequence [58], which accepts an adjusted flexible and extended conformation. It is capable of reaching certain epitopes inaccessible to conventional antibodies [59], such as the active sites of enzymes and GPCRs [60].

In addition to its naturally high binding capacity, $\mathrm{V}_{\mathrm{H}} \mathrm{H}$ also has a more favorable structure in terms of its in vivo immunogenicity, solubility, and stability. The high sequence similarity of $\mathrm{V}_{\mathrm{H}} \mathrm{H}$ to the human $\mathrm{V}_{\mathrm{H}}$ gene family III makes it more compatible for human use and less immunogenic in vivo [56]. Typically, nanobodies only require minor sequence amendments for a humanization process [61]. Furthermore, without light chains and $\mathrm{CH}_{1}$ domains, the $\mathrm{V}_{\mathrm{H}} \mathrm{H}$ domain is more soluble and stable as compared with those of $\mathrm{V}_{\mathrm{H}}$ and $\mathrm{V}_{\mathrm{L}}$ in the traditional antibodies. Compared with $\mathrm{scFv}, \mathrm{V}_{\mathrm{H}} \mathrm{H}$ antibodies avoid the potential disrupted interaction between variable domains $\left(\mathrm{V}_{\mathrm{H}}, \mathrm{V}_{\mathrm{L}}\right)$ and constant domains $\left(\mathrm{CH}_{1}, \mathrm{C}_{\mathrm{L}}\right)$ and the exposure of hydrophobic patches. Such disrupted interaction and hydrophobic residues may severely affect the solubility and stability [42]. Due to these properties, the nanobody holds a unique potential in developing various forms of CAR-T [62], and many studies have explored nanobody-based CAR constructs over the years [63].

\section{The Applications of Nanobodies in CAR-T Therapies}

As listed in Table 1, many efforts have already been made to develop CAR-T therapies using nanobodies because of their widely recognized advantages. The first published CAR-modified $\mathrm{T}$ cell with a nanobody utilized the anti-MUC1 $\mathrm{V}_{\mathrm{H}} \mathrm{H}$ as the target binding domain [64]. The retrieved nanobody was joined with the human IgG3 hinge and IgG3-Fc as a spacer, while CD28 and CD3 $\zeta$ were introduced as signaling domains. After the CAR has been transduced in Jurkat cells, an increased proliferation was observed upon co-culturing with $\mathrm{MUC1}^{+} \mathrm{MCF7}$ tumor cells. Moreover, the transduced Jurkat cells showed activity in cell lysis and IL2 secretion. Even though different hinges, such as IgG3-Fc-hinge and IgG3Fc-hinge-hinge, were utilized in constructing CAR, the corresponding engineered Jurkat $\mathrm{T}$ cells maintain a similar IL2 secretion and proliferation upon the stimulation. However, the CAR with the use of an Fc $\gamma$ RII hinge revealed a significant reduction in CAR expression and IL2 secretion. 
Table 1. The applications of nanobodies in CAR-T therapies.

\begin{tabular}{|c|c|c|c|c|c|}
\hline \multirow{2}{*}{ Target } & \multicolumn{4}{|c|}{ CAR Structure } & \multirow{2}{*}{ Reference } \\
\hline & Spacer & Transmembrane & Costimulatory & Signaling & \\
\hline \multirow{5}{*}{ MUC1 } & IgG3-Fc\&Hinge & \multirow{3}{*}{ CD28 } & \multirow{3}{*}{ CD28 } & \multirow{3}{*}{$\mathrm{CD} 3 \zeta$} & \multirow{3}{*}[64,65]{} \\
\hline & IgG3-Fc\&Hinge-Hinge & & & & \\
\hline & FC $\gamma$ RII Hinge & & & & \\
\hline & IgG3-Fc\&Hinge & \multirow{2}{*}{$\mathrm{CD} 28$} & \multirow{2}{*}{ CD28-OX40 } & \multirow{2}{*}{$\mathrm{CD} 3 \zeta$} & \multirow{2}{*}{ [66] } \\
\hline & IgG3-Fc\&Hinge-Hinge & & & & \\
\hline \multirow{4}{*}{ TAG-72 } & IgG3-Fc\&Hinge & \multirow{4}{*}{$\mathrm{CD} 28$} & \multirow{2}{*}{$\mathrm{CD} 28$} & \multirow{2}{*}{$\mathrm{CD} 3 \zeta$} & \multirow{4}{*}{ [67] } \\
\hline & IgG3-Fc\&Hinge-Hinge & & & & \\
\hline & IgG3-Fc\&Hinge & & \multirow{2}{*}{ CD28-OX40 } & \multirow{2}{*}{$\mathrm{CD} 3 \zeta$} & \\
\hline & IgG3-Fc\&Hinge-Hinge & & & & \\
\hline \multirow{4}{*}{ HER2 } & IgG3-Fc\&Hinge & \multirow{4}{*}{ CD28 } & \multirow{2}{*}{$\mathrm{CD} 28$} & \multirow{2}{*}{$\mathrm{CD} 3 \zeta$} & \multirow{4}{*}{ [68] } \\
\hline & IgG3-Fc\&Hinge-Hinge & & & & \\
\hline & IgG3-Fc\&Hinge & & \multirow{2}{*}{ CD28-OX40 } & \multirow{2}{*}{$\mathrm{CD} 3 \zeta$} & \\
\hline & IgG3-Fc\&Hinge-Hinge & & & & \\
\hline VEGFR2 & IgG1-Fc & CD28 & CD28 & $\mathrm{CD} 3 \zeta$ & [69] \\
\hline PSMA & IgG1-Fc & CD28 & CD28 & $\mathrm{CD} 3 \zeta$ & [70] \\
\hline $\mathrm{GPC}^{\mathrm{a}}$ & CD $8 \alpha$ & $\mathrm{CD} 8 \alpha$ & 4-1BB & $\mathrm{CD} 3 \zeta$ & [71] \\
\hline PD-L1 & \multirow{2}{*}{ CD8 $\alpha$} & \multirow{2}{*}{$\operatorname{CD} 8 \alpha$} & \multirow{2}{*}{ CD28 } & \multirow{2}{*}{$\mathrm{CD} 3 \zeta$} & \multirow{2}{*}{ [72] } \\
\hline EIIIB & & & & & \\
\hline CD38 & $\mathrm{CD} 8 \alpha$ & $\mathrm{CD} 8 \alpha$ & $4-1 \mathrm{BB}$ & $\mathrm{CD} 3 \zeta$ & [73] \\
\hline $\mathrm{CD} 38^{\mathrm{b}}$ & IgG4-Hinge & CD28 & CD28-4-1BB & $\mathrm{CD} 3 \zeta$ & [74] \\
\hline BCMA $^{c}$ & $\mathrm{CD} 8 \alpha$ & $\mathrm{CD} 8 \alpha$ & 4-1BB & $\mathrm{CD} 3 \zeta$ & {$[75,76]$} \\
\hline BCMA & CD8 $\alpha$ & $\operatorname{CD} 8 \alpha$ & $4-1 \mathrm{BB}$ & $\mathrm{CD} 3 \zeta$ & [77] \\
\hline CD20 & $\mathrm{CD} 8 \alpha$ & $\mathrm{CD} 8 \alpha$ & $4-1 \mathrm{BB}$ & $\mathrm{CD} 3 \zeta$ & \multirow{2}{*}{ [78] } \\
\hline CD33 & $\mathrm{CD} 8 \alpha$ & $\mathrm{CD} 8 \alpha$ & $4-1 \mathrm{BB}$ & $\mathrm{CD} 3 \zeta$ & \\
\hline
\end{tabular}

The PhiC31 integrase system was further employed to optimize the CAR transduction and expression efficiency, which is encoded by a phage of streptomyces soil bacteria [79]. It is able to integrate introduced plasmid DNA into preferred locations in unmodified mammalian genomes, resulting in the robust, long-term expression of the integrated transgene [80]. By flow cytometry, the expression of anti-MUC1 CAR has been detected on the surface of Jurkat cells at day 1 and 30 after transfection. At day 1, there is not much difference in CAR expression between conditions with and without the use of a PhiC31 integrase system. However, the CAR expressions are above $50 \%$ at day 30 after transfection with the use of the PhiC31 integrase system. Contrarily, the CAR expression is hardly detected at day 30 in the control system. As the relative CAR mRNA expressions are compared, the PhiC31 integrase system achieved an approximately 10-fold enhancement of CAR expression in Jurkat cells. This suggested that the PhiC31 integrase system displayed a much higher efficiency at least in this specific case [65]. As a proof-of-concept, the introduction of nanobodies in CAR-T cells demonstrates similar activities to those of $\mathrm{scFv}$ from the CAR structure compatibility to cell functions.

Encouraged by the feasibility of anti-MUC1 nanobody in CAR constructs, nanobodies against TAG-72 [67] and HER2 [68] were constructed into second-/third-generation CARs subsequently. As many as $13 \mathrm{~V}_{\mathrm{H}} \mathrm{Hs}$ have been identified to interact with the immobilized 
TAG-72 and TAG-72 ${ }^{+}$tumor cell, LS-174T. A $\mathrm{V}_{\mathrm{H}} \mathrm{H}, \mathrm{N} 13$, was selected to construct anti-TAG72 CAR. The anti-TAG-72 CAR-T proliferates in specific response to the TAG-72-positive tumor cell lines of LS-174T and MCF7. In addition, the CAR-T cells show IL2 secretion and specific cell lysis upon tumor cell engagement. Five $\mathrm{V}_{\mathrm{H}} \mathrm{Hs}$ were selected from an immunized camel with the use of HER2, which were joined into CD28-CD3 $\xi$ and CD28OX40-CD3 $\xi$ signaling endodomains. Interestingly, the anti-HER2 CARs, constructed by the oligocolonal $\mathrm{V}_{\mathrm{H}} \mathrm{Hs}$ or individual $\mathrm{V}_{\mathrm{H}} \mathrm{H}$, which are both transduced into Jurkat $\mathrm{T}$ cells. The oligoclonal $\mathrm{V}_{\mathrm{H}} \mathrm{H}$-CAR-engineered Jurkat $\mathrm{T}$ cells revealed a higher proliferation, IL2 secretion, and cytotoxicity.

The VEGFR2 (fetal liver kinase-1, FLK1, or kinase-insert domain receptor, KDR), belonging to the human VEGF receptor 1-3 family, is over-expressed on tumor vasculatures and is a promising anti-angiogenic target [81]. Although multiple chemical drugs and a Mab have been approved on marketing by targeting the VEGF/VEGR axis, challenges remain in their applications in T cell-based therapies. This is partially due to their immunosuppressive effects by inhibiting the activities of DC and effective T cells, enhancing the presence of Treg and MDSCs [82,83]. Nevertheless, a single dose of VEGFR2 CARengineered $\mathrm{T}$ cells significantly inhibited the growth of five different types of tumors in mice [84]. Therefore, if the numbers of adoptively transferred anti-VEGFR2 CAR-T cells are carefully escalated in the clinic, and safety mechanisms are introduced deliberately, the "On-target/Off-tumor" toxicity might be minimized [85].

A nanobody has been generated from two young male camels by injecting VEGFR2overexpressing cells subcutaneously for six times at monthly interval. One nanobody, named 3VGR19, bound VEGFR2 with a $K_{D}$ value of $5.4 \mathrm{nM}$ as measured by surface plasmon resonance (SPR). As demonstrated by FACS, this nanobody could selectively recognize VEGFR2-overexpressing tumor cells and primary endothelial cells (HUVECs). Following an in vitro assay, the capillary-like structures were successfully suppressed due to the blockage of VEGFR2 by the nanobody [86]. It indicated that 3VGR19 could block VEGFR2 signaling and thereby providing a potential application. The nanobody was further constructed into the second-generation CAR with the signaling domains of CD28 and $\mathrm{CD} 3 \zeta$. The resulting CAR-T cells display around $50 \%$ positive expression on the cell surface, which secretes IL-2 and IFN- $\gamma$ and displays cytotoxic activity upon coculturing with VEGFR2-positive cells [69].

Prostate-specific membrane antigen (PSMA) is a classic target for prostate cancer that has attracted much attention for in drug discovery. A nanobody was generated from a llama immunized with four human-derived prostate cancer cell lines. The identified nanobody, JVZ-007, has the highest binding affinity with a $K_{D}$ value of $22.4 \mathrm{nM}$ [87]. JVZ-007 was constructed with the CD28 transmembrane, co-stimulatory domain and CD3 , signaling domain, which responded to PSMA ${ }^{+}$tumor cells, LNCaP and DU-145, by inducing IL2 and INF- $\gamma$ secretion and increasing CD69 expression. It provided the support to CAR-T cells in PSMA-targeted immunotherapy [70].

The human $\mathrm{V}_{\mathrm{H}}$ single-domain antibody library was firstly constructed by introducing both diverse human CDR2s and CDR3s plus synthetic CDR1s. The CDR1s are composed of random mutations of four putative solvent-accessible residues, A/D/S/Y. All these CDRs are combined into a human $\mathrm{V}_{\mathrm{H}}$ single-domain framework, which results in a phage-display engineered library [88]. By this kind of library, a panel of $\mathrm{V}_{\mathrm{H}}$ single domain antibodies with specificity to GPC2 were retrieved by the phage display and the lead nanobody displayed the binding affinity with a $K_{D}$ value of $9.8 \mathrm{nM}$. The produced CARs targeting GPC2 have been expressed in T cells isolated from eight individual healthy human donors. GPC2-specific CAR-T cells can efficiently lytic IMR5 neuroblastoma cells with high-level expression of GPC2. The CAR-T cells were generated from eight individual human donors to evaluate the killing ability. At an effector:target ratio of 8:1, GPC2-specific CAR-T cells reveal the cytotoxicty against IMR5 neuroblastoma cells ranged from $44 \%$ to $71 \%$, with an average of $56 \%$. In addition, the GPC2 CAR-T cells effectively suppressed the metastatic 
tumors or reduced the tumor size significantly in nude mice i.v. engrafted with IMR5 cells [71].

Two nanobodies, B3 and A12, were generated through immunizing alpaca by recombinant ectodomain of mouse PD-L1, which interact specifically with mouse PD-L1 on overlapping epitopes with the estimated affinities in the low $\mathrm{nM}$ range [89]. After adjoining A12 as PD-L1 binder in second generation CAR as shown in Table 1, the resulting CAR-T cells are capable of effectively lyse PD-L1 expressed cancer cell lines in a dose-dependent manner. These cell lines include B16 melanoma, an HPV16-transformed cell C3.43. and a colon adenocarcinoma MC38, thereby supporting its potential across a spectrum of cancers [72]. However, both macrophages and other immune cells express PD-L1 [90-92], which complicated the clinical application of this type of CAR-T therapy [72].

EIIIB is an alternatively spliced domain of fibronectin which is strongly expressed in tumors and during angiogenesis but with an extremely restricted distribution in normal adult tissues [93]. A nanobody library was generated from an alpaca immunized by a mixture of extracellular proteins (ECM), including full-length proteins, truncated domains, and peptides. After two rounds of panning, a nanobody, NJB2, was identified to bind specifically EIIIB with a $K_{D}$ value of $1.9 \mathrm{nM}$ [94]. NJB2 was further utilized to generate CAR-T cells, displaying high transduction rate and specific cytotoxicity in vitro. The CAR$\mathrm{T}$ cells were further proved to delay the tumor growth and improved the survival of WT C57BL/ 6 mice inoculated with B16 tumors. However, the treatment with CAR-T cells achieved minimal effects on the survival or tumor growth in the MC38 colon carcinoma model because of its low expression of EIIIB. In addition, low levels of immunogenicity against the CAR had been observed in a few mice, but no visible side effects developed upon repeated administration. No correlation had been observed between immunogenicity and animal survival [72].

Although CD38 expresses ubiquitously in many cells, especially in immune cells, it still remained an attractive target due to the extremely high expression levels in some malignant tumors [95]. The conventional CD38-specific mAb daratumumab [96] and isatuximab [97] have demonstrated their clinic efficacies in multiple myeloma. The advances have encouraged the development of CAR-T therapies. The purified recombinant C-terminal of CD38 was used to immunize llamas and the resulting nanobodies recognized CD38 at three different epitopes as revealed by crystallographic studies [98]. The nanobody against CD38, $\mathrm{Nb}-1 \mathrm{G} 3$, recognized the highly antigenic epitope located at the C-terminal region with a $K_{D}$ value of $4.11 \mathrm{nM}$ [73]. The construction of $\mathrm{Nb}-1 \mathrm{G} 3$ with the $\mathrm{CD} 8 \alpha$ hinge and transmembrane, 4-1BB co-stimulatory and CD3 $\zeta$ activation domains to generate CAR-T cells, which demonstrated a high cytotoxic activity against $\mathrm{CD} 38$-positive fractions of $\mathrm{T}$ cells, $\mathrm{B}$ cells and natural killer cells in vitro. As expected, these CAR-T cells were able to effectively inhibit the tumor growth in NOD/SCID mice that were subcutaneously inoculated with RPMI 8226 cells [73]. In addition to CAR-T, another study utilized three nanobodies, WF211, MU1067 and JK36, targeting different epitopes, to construct CARs, and they showed similar dissociation rate constants ranging from $4.5 \times 10^{-3}$ to $1.2 \times 10^{-4} \mathrm{~s}^{-1}$ [99]. After adjoining the nanobody to CARs separately, as shown in Table 1, they were transduced into the engineered human natural killer cell line by the CRISPR/Cas9, NK-92 ${ }^{\mathrm{CD} 38 \mathrm{ko}}$, and stably expressed. The resulting CAR-NK cells provoked a specific, effective, and comparable cytotoxicity on CD38-expressing tumor cell lines independent of which nanobody was used or which epitope was targeted. Their cell lytic activities occurred in both, a timeand dose-dependent manner. These CD38-directed CAR-NK cells further displayed their activities against primary multiple myeloma cells from eight patients [74].

For the CD33 antigen, the soluble ectodomain was used to immunize a llama. The immunized PBMC served to construct a nanobody library for phage display selections. The achieved nanobody was constructed as listed in Table 1. It specifically lysed CD33positive acute myeloid leukemia cell lines, including U937, HL60 and MOLM13 and Thp1. The xenograft model was established by intravenously injecting Thp1 cells in NGS mice for seven days. The engrafted mice were administrated by a single tail vein injection of 
anti-CD33 CAR-T cells. As compared with PBS, the treatments of CAR-T cells brought a reduction in tumor burden and improved survival rate [78]. As expected, anti-CD33 CAR-T cells caused an on-target/off-tumor effect because CD33 is also expressed on myeloid progenitors.

CD20 is another attractive target. However, CD20 is a multiple-pass transmembrane protein and difficult to purify, besides its exposed extracellular parts are too short to form well-folded structural domains. Therefore, the researchers preferred to immunize a llama with an expression DNA vector encoding full-length CD20. Three nanobodies were identified from immunized Nanobody library, which all show vigorously cytotoxic activity on $\mathrm{CD}_{20}{ }^{+}$cell lines, such as the Burkitt lymphoma cell line Raji and non-Hodgkin B lymphoblast cell line RL. In addition, the CAR-T cell targeting CD20 demonstrated significant in vivo function by eliminating the complete subcutaneous tumor in less than 20 days and prolonging the survival of mice remarkably [78].

The targets and corresponding CARs utilizing a nanobody listed in Table 1 supported the potential applications of such CARs by both cell-based assays and mouse models. However, their clinical effects are still unavailable except for BCMA. Two independent nanobody modules targeting BCMA have been developed and demonstrated their significant clinic effects on relapse/refractory multiple myeloma. One project has been developed by Pregene Biopharma and its CAR construct has been composed of a monovalent anti-BCMA nanobody, 4-1BB and CD3 (PRG1801) [77]. The other anti-BCMA CAR was constructed by Nanjing Legend Biotech, which employed two nanobodies recognizing BCMA in a bi-epitopic manner [75,76]. Both co-stimulatory and signaling domains are identical. Based on the public data, their clinical effects are both comparable to that of bb2121, which is developed by Bluebird with the use of an ScFv to BCMA [100].

These nanobodies are generated from flexible immunization approaches, which ranges from expression DNA vector [78], recombinant proteins [99], stable cell lines [86] to cancerous tissues [101]. The $\mathrm{V}_{\mathrm{H}} \mathrm{H}$ repertoires are established from peripheral blood lymphocytes and usually displayed on phage [86]. The panning processes are variable and depends on the availability of antigen. It is notable that the affinities of nanobodies are typically within a $K_{D}$ value of 1-10 $\mathrm{nM}$ for CAR construction. It provides the indication on the nanobody selection although the target expression and tissue distribution should be included in the consideration. However, the characterization of $\mathrm{V}_{\mathrm{H}} \mathrm{H}$ are not generally included in the discovery of nanobodies for CAR-T therapy. It is postulated that antibody discovery follows the well-known procedure.

\section{Nanobody in Advanced CAR}

As shown in Figure 2, the aggregation of CARs due to the antigen binding domain, $\mathrm{scFv}$, may induce excessive tonic signaling by an antigen-independent manner and eventually cause early exhaustion of T cells [54]. The nanobodies become an attractive and convenient module to develop the advanced and fourth-generation CARs. Table 2 shows the first nanobody-based CAR, targeting MUC1, that has been attempted on two intracellular domains. In addition, authors added a caspase8-induced suicide switch [102] to regulate the proliferation and to reduce potential unwanted side effects in vivo. During an in vitro assay, the suicide of CAR-T cells was triggered by adding a protein variant to a final concentration of $10 \mathrm{nM}$ [66].

Table 2. The applications of nanobodies in advanced CAR-T therapies.

\begin{tabular}{|c|c|c|c|c|c|c|}
\hline \multirow{2}{*}{ Target } & \multicolumn{5}{|c|}{ CAR Structure } & \multirow{2}{*}{ Reference } \\
\hline & Spacer & Transmembrane & Costimulatory & Signaling & New Function & \\
\hline MUC1 & IgG3-Fc\&Hinge-Hinge & CD28 & CD28-OX40 & $\mathrm{CD} 3 \zeta$ & iCaspase 8 & {$[66]$} \\
\hline \multirow[b]{2}{*}{ EGFR } & Anti-E5B9-CD28 & CD28 & CD28 & $\mathrm{CD} 3 \zeta$ & UniCAR & [103] \\
\hline & Anti-E5B9-CD28 & CD28 & CD28 & $\mathrm{CD} 3 \zeta$ & $\begin{array}{l}\text { UNiCAR \& } \\
\text { Bivalent } \mathrm{V}_{\mathrm{H}} \mathrm{H}\end{array}$ & [104] \\
\hline
\end{tabular}


Table 2. Cont.

\begin{tabular}{|c|c|c|c|c|c|c|}
\hline \multirow{2}{*}{ Target } & \multicolumn{5}{|c|}{ CAR Structure } & \multirow{2}{*}{ Reference } \\
\hline & Spacer & Transmembrane & Costimulatory & Signaling & New Function & \\
\hline CD20\&HER2 & IgG1-Fc & CD28 & CD28 & $\mathrm{CD} 3 \zeta$ & Bispecific & [105] \\
\hline \multirow{3}{*}{ PD-L1 } & $\operatorname{CD} 8 \alpha$ & $\operatorname{CD} 8 \alpha$ & CD28 & $\mathrm{CD} 3 \zeta$ & $\begin{array}{c}\text { secrete } \\
\text { anti-CD47 }\end{array}$ & \multirow{6}{*}{ [106] } \\
\hline & $\operatorname{CD} 8 \alpha$ & $\operatorname{CD} 8 \alpha$ & CD28 & $\mathrm{CD} 3 \zeta$ & $\begin{array}{c}\text { secrete } \\
\text { anti-CD47-Fc }\end{array}$ & \\
\hline & $\operatorname{CD} 8 \alpha$ & $\operatorname{CD} 8 \alpha$ & CD28 & $\mathrm{CD} 3 \zeta$ & $\begin{array}{l}\text { secrete anti- } \\
\text { CTLA4-Fc\& } \\
\text { anti-CD47 }\end{array}$ & \\
\hline \multirow{3}{*}{ EIIIB } & $\operatorname{CD} 8 \alpha$ & $\operatorname{CD} 8 \alpha$ & CD28 & $\mathrm{CD} 3 \zeta$ & $\begin{array}{c}\text { secrete } \\
\text { anti-PD-L1 }\end{array}$ & \\
\hline & $\operatorname{CD} 8 \alpha$ & $\operatorname{CD} 8 \alpha$ & CD28 & $\mathrm{CD} 3 \zeta$ & $\begin{array}{c}\text { secrete } \\
\text { anti-CD47 }\end{array}$ & \\
\hline & $\operatorname{CD} 8 \alpha$ & $\operatorname{CD} 8 \alpha$ & CD28 & $\mathrm{CD} 3 \zeta$ & $\begin{array}{c}\text { secrete } \\
\text { anti-CTLA4-Fc }\end{array}$ & \\
\hline
\end{tabular}

As shown in Figure 3, bispecific CAR-T cells are believed to reduce the possibility of tumor escape by the loss of the target expression on tumor cells. $\mathrm{V}_{\mathrm{H}} \mathrm{Hs}$ are devoid of light chains and are able to avoid domain swapping when multiple nanobodies are expressed simultaneously. A bispecific CAR-T cell was constructed by two nanobodies which target HER2 and CD20, respectively. Bispecific CAR-T cells display a similar activity to CD20and HER2-expressing cells. They provide an option to circumvent tumor resistance after the loss of one antigen expression, although no clinical data are yet available [105]. In contrast, LCAR-B38M CAR-T cells revealed the feasibility of two nanobodies to target two epitopes on the extracellular domain of BCMA $[99,100,106,107]$. This construct could be manufactured and was effective in the clinic, as shown in Table 1. It demonstrated advantages and revealed the feasibility of replacing scFvs by nanobodies in generating bispecific CAR-T cells.

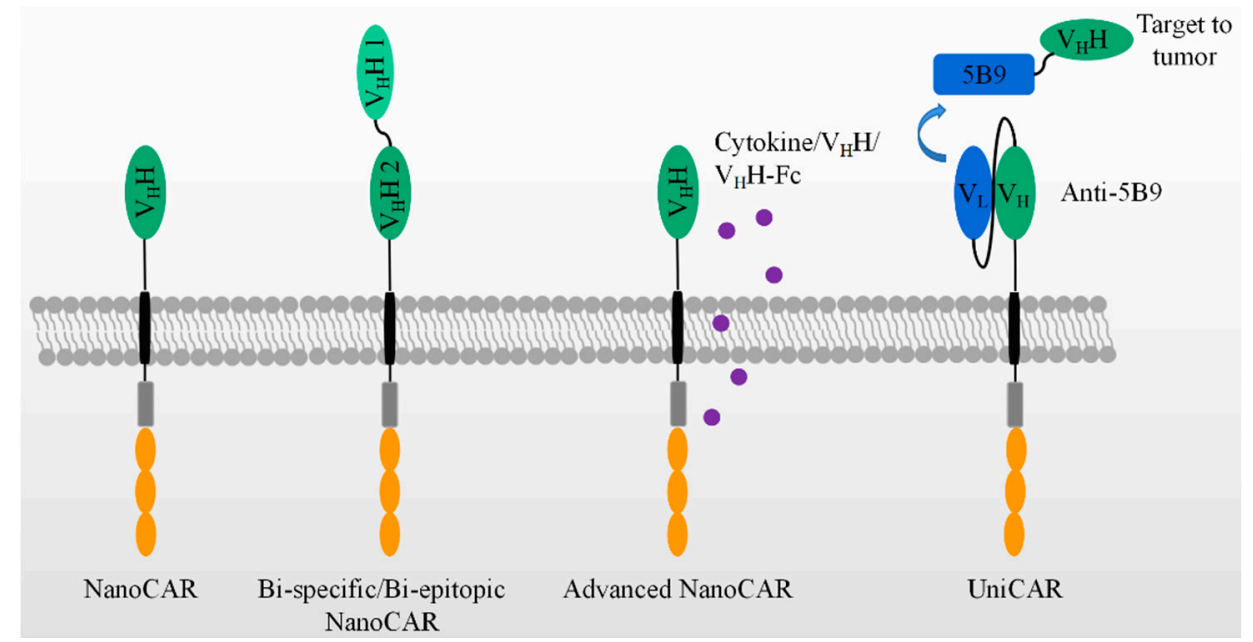

Figure 3. The application of $\mathrm{V}_{\mathrm{H}} \mathrm{H}$ in advanced CAR-T therapies, which include bi-specific/epitopic, cytokine $/ \mathrm{V}_{\mathrm{H}} \mathrm{H} / \mathrm{V}_{\mathrm{H}} \mathrm{H}-\mathrm{Fc}$ releasing, and UniCAR, etc.

Besides fourth-generation CAR-T with the secretion of cytokines, many have been paid to explore the variable formats of antibody secretion with the use of NanoCAR-T therapies, as listed in Table 2. In comparison with $\mathrm{scFv}$, the smaller size of a nanobody facilitates 
its insertion into a DNA construct. CAR-T cells were constructed with an anti-PD-L1 nanobody and an extra anti-CD47 $\mathrm{V}_{\mathrm{H}} \mathrm{H}$ secretion system. As performed in PD-L1 ${ }^{+}$B16F10 cell, the INF- $\gamma$ releasing and killing activity showed no difference between anti-PD-L1- and anti-47-secreting anti-PD-L1 CAR-T cells. However, as a C57BL/6 PD-L1 KO mouse was inoculated by B16F10 at day one, the treatments have been carried out by variable doses of anti-PD-L1 CAR-T cells at day 2, 6, and 12. The anti-CD47 secretion anti-PD-L1 CAR-T cells display better effects on the tumor sizes and mice survival than that of anti-PD-L1 CAR-T cells plus the systematic administration of anti-CD47 and anti-PD-L1 CAR-T-only groups. In addition, the anti-CD47 was secreted by CAR-T cells constructing an anti-EIIIB nanobody. The use of the treatments of these CAR-T cells on an in vivo model in C57BL/6 wild mouse showed an improved survival, as compared with that of anti-EIIIB CAR-T cells. Thus, anti-CD47-secreting anti-PD-L1 CAR-T cells improved the anti-tumor activity and achieved a significant survival benefit from an epitope-spreading mechanism.

In Table 2 , the authors further construct a series of $\mathrm{V}_{\mathrm{H}} \mathrm{H}$ or / and $\mathrm{V}_{\mathrm{H}} \mathrm{H}$-Fc secreting anti-PD-L1/EIIIB CAR-T cells. No significant survival benefit has been observed in an in vivo mouse model. However, it is obvious that $\mathrm{V}_{\mathrm{H}} \mathrm{H}$ or/and $\mathrm{V}_{\mathrm{H}} \mathrm{H}-\mathrm{Fc}$ can be locally delivered by the secretion of CAR-T cells [106].

Figure 3 also shows a universal modular platform termed UniCAR which was established to reduce the on-target/off-tumor side effects by the reversible and rapid control of CAR-T cell activity. The UniCAR technology splits the intracellular signaling and antigen-binding domain into two individual components. Structurally, the cellular part was composed of a scFv antibody, CD28 $\alpha$ costimulatory, and CD3 $\zeta$ signaling, as listed in Table 2. The scFv in the cellular part is able to specifically recognize a short peptide, 5B9. This construct was packaged into lentivirus and added to engineer human primary $\mathrm{T}$ cells. The target module included a tumor-specific nanobody and the short peptide, 5B9. This nanobody fused to the 5B9 tag was provided separately as a second and interchangeable component. In a mouse model, the UniCAR system is by itself totally inert in vivo unless the tumor-specific nanobody fused with the 5B9 tag is additionally administered [107]. Recently, an anti-EGFR nanobody fused with the 5B9 tag at its C-terminal was shown to activate and redirect the UniCAR-T cell to the EGFR-positive tumor cells both in vitro and in a mouse tumor xenograft model. By PET imaging, the nanobody can assemble to UniCAR reversibly [103]. Once the nanobody-5B9 was dissociated from UniCAR, the CAR-T cells were turned off, as expected. The same team further constructed a bivalent anti-EGFR nanobody that achieved a higher avidity than the monovalent nanobody. The bivalent nanobody fusion containing the 5B9 tag exerted its activity on the tumor cells, even those with a low antigen expression, after loading on UniCAR T cells. In comparison, the monovalent nanobody system could only redirect UniCAR T cells to tumor cells with a higher antigen expression [104].

\section{The Clinical Effects of Different Anti-BCMA CAR-T Cells}

Nanobodies have demonstrated their potential and feasibility in the discovery and development of CAR-T therapies. PRG1801 is composed of a monovalent anti-BCMA nanobody, 4-1BB, and CD3 $\zeta[77,108]$, while the other anti-BCMA CAR-T developed by Nanjing Legend Biotech employed two nanobodies recognizing BCMA in a bi-epitopic manner $[75,76,109,110]$. Based on the published data, their clinical effects are both comparable to that of bb2121, which was developed by Bluebird with the use of an scFv targeted BCMA [100]. A comparison of the clinical data for three different BCMA-targeting CAR-T cells is listed in Table 3, including the CAR-T targeting BCMA using antigen recognition $\mathrm{scFv}$, bi-epitopic tandem $\mathrm{V}_{\mathrm{H}} \mathrm{Hs}$, or single humanized $\mathrm{V}_{\mathrm{H}} \mathrm{H}$. 
Table 3. The summary of clinical efficacies and side effects from three independent anti-BCMA CAR T cells.

\begin{tabular}{|c|c|c|c|c|c|}
\hline & $\begin{array}{l}\text { bb2121 (128/33 } \\
\text { Cases) [100] }\end{array}$ & $\begin{array}{l}\text { LCAR-B38M (57 } \\
\text { Cases) [75] }\end{array}$ & $\begin{array}{l}\text { LCAR-B38M (17 } \\
\text { Cases) [76] }\end{array}$ & $\begin{array}{c}\text { LCAR-B38M/JNJ- } \\
4528 \text { (97 Cases) } \\
\text { [110] }\end{array}$ & $\begin{array}{c}\text { PRG1801 (34 Cases) } \\
{[77,108]}\end{array}$ \\
\hline Antigen Module & Humanized scFv & & Bi-epitopic tandem $\mathrm{V}_{\mathrm{H}} \mathrm{Hs}$ & & $\begin{array}{l}\text { Single humanized } \\
\qquad \mathrm{V}_{\mathrm{H}} \mathrm{H}\end{array}$ \\
\hline Dosage & $\begin{array}{l}50 \times 10^{6}, 150 \times 10^{6}, \\
450 \times 10^{6}, 800 \times 10^{6}\end{array}$ & $\begin{array}{l}\text { Median dose, } 0.5 \times \\
10^{6} \text { cells } / \mathrm{kg}\end{array}$ & $\begin{array}{l}\text { Median dose, } 0.7 \times \\
10^{6} \text { cells } / \mathrm{kg}\end{array}$ & $\begin{array}{c}\text { Median dose, } 0.75 \times \\
10^{6} \text { cells } / \mathrm{kg}\end{array}$ & $\begin{array}{c}\text { Median dose, } 5 \times 10^{6} \\
\text { cells } / \mathrm{kg}\end{array}$ \\
\hline Efficacy & $\begin{array}{c}\text { ORR, } 73 \% ; \\
\text { CR/sCR, } 31 \%\end{array}$ & $\begin{array}{l}\text { ORR, } 88.0 \% ; \\
\text { CR, } 68.0 \%\end{array}$ & $\begin{array}{l}\text { ORR, } 88.2 \% ; \\
\text { CR, } 76.5 \%\end{array}$ & $\begin{array}{l}\text { ORR, } 94.8 \% \\
\text { sCR, } 56.0 \%\end{array}$ & $\begin{array}{l}\text { ORR, } 88.2 \% \\
\text { SCR, } 55.9 \%\end{array}$ \\
\hline \multirow{4}{*}{$\begin{array}{c}\text { Grade } 3 \text { or higher } \\
\text { hematologic toxic } \\
\text { effects }\end{array}$} & $\begin{array}{l}\text { Neutropenia, } 85 \% \text {; } \\
\text { (33 cases) }\end{array}$ & Leukopenia, 30\% & Neutropenia, $47.1 \%$ & Neutropenia, $90.7 \%$ & Neutropenia, $44.1 \%$; \\
\hline & $\begin{array}{l}\text { Leukopenia, } 58 \% ; \\
\text { (33 cases) }\end{array}$ & $\begin{array}{c}\text { Thrombocytopenia, } \\
23 \%\end{array}$ & Leukopenia, 58.8\% & - & Leukopenia, $32.4 \%$ \\
\hline & $\begin{array}{l}\text { Anemia, } 45 \% \\
\text { (33 cases) }\end{array}$ & - & $\begin{array}{c}\text { Thrombocytopenia, } \\
17.6 \%\end{array}$ & Anemia, $68 \%$ & Anemia, $20.6 \%$ \\
\hline & $\begin{array}{l}\text { Thrombocytopenia, } \\
45 \% \text { ( } 33 \text { cases) }\end{array}$ & - & - & $\begin{array}{l}\text { Thrombocytopenia, } \\
59.8 \%\end{array}$ & $\begin{array}{c}\text { Thrombocytopenia, } \\
38.2 \%\end{array}$ \\
\hline \multirow[b]{2}{*}{ Neurotoxicity } & Grade 1 or $2,14.8 \%$; & \multirow[b]{2}{*}{ Grade $1,1.8 \%$} & \multirow[t]{2}{*}{ - } & Grade 1 or $2,10.3 \%$ & \multirow[t]{2}{*}{ - } \\
\hline & Grade $4,3 \%$ & & & $\begin{array}{c}\text { Grade } 3 \text { or higher, } \\
10.3 \%\end{array}$ & \\
\hline \multirow[b]{2}{*}{ CRS } & Grade 1 or $2,79 \%$ & Grade 1 or $2,83 \%$ & Grade 1 or $2,58.8 \%$ & \multirow{2}{*}{$\begin{array}{c}\text { Grade } 3 \text { or higher, } \\
4.1 \%\end{array}$} & Grade 1 or $2,82.4 \%$ \\
\hline & Grade $3,5.4 \%$ & Grade 3,7\% & $\begin{array}{c}\text { Grade } 3 \text { or higher, } \\
41.2 \%\end{array}$ & & Grade 3, 2.9\% \\
\hline
\end{tabular}

As shown in Table 3, the clinical dose of bb2121 was $150-300 \times 10^{6}$ CAR-positive cells, the LCAR-B38M was $0.5-0.75 \times 10^{6} / \mathrm{kg}$ body weight, and the PRG1801 was $2-10 \times 10^{6} / \mathrm{kg}$ body weight. Based on the published data of bb2121, the Objective Response Rate (ORR) is $73 \%$, and the Complete Response/stringent Complete Response (CR/sCR) is $31 \%$. The data of LCAR-B38M from three independent clinical trials showed that their ORRs ranged from $80 \%$ to $94.8 \%$. Their CRs / sCRs ranged from $56 \%$ to $76 \%$. Another anti-BCMA nanobodybased CAR-T with a 2nd-generation CAR, PRG1801, has been used to treat 34 patients in a clinical study (NCT03661554). Within the median follow-up time of 12.5 months, 30 patients, representing $88.2 \%$, had the best overall response, and $19(55.9 \%)$ of them achieved complete remission $[77,108]$.

The adverse events, including hematologic toxic effects, CRS, and neurotoxicity, for three anti-BCMA CAR-T therapies were controllable and comparable, although differences were found in the neurotoxicity. The CRS and neurotoxicity are the main adverse events related to CAR-T and were primarily caused by the excessive cytokine release [111-113]. BB2121 showed a mild severity and average frequency compared with other CAR-Ts, aside from the BCMA targeted, with an $84.4 \%$ overall CRS frequency and $5.4 \%>$ Grade 3 CRS and $17.8 \%$ overall neurotoxicity. LCAR-B38M showed more severe neurotoxicity, with a $20.6 \%$ overall occurrence and $10.3 \%$ Grade 3 or higher occurrence, which was probably due to the higher cytotoxic activity of the CAR-T with bi-epitopic tandem binding domains. PRG1801 revealed a relatively slight severity and lower frequency of adverse events, with $2.9 \%$ with Grade 3 CRS and no neurotoxicity observed. The safety data further showed promising results for nanobody-derived CAR-T in treating blood cancer, indicating that nanobodies with its special and beneficial characteristics can be broadly applied in CAR-T cellular drug development.

\section{Summary}

The anti-tumor effects of $\mathrm{T}$ cells have been recognized for about half a century. They evolved from "clinically effective/undefined targets" to "clinically ineffective/specific targets" to "clinically effective/defined targets". CAR-T cell therapy is only one of its applications. Over a dozen targets have been modulated by nanobody-based CARs, which 
display similar activities to those of scFv. By the thoughtful application of its advantages, nanobody-based CARs have been extensively explored by broadening their therapeutic potential. Remarkably, no matter whether BCMA is modulated by a single nanobody or bivalent nanobodies, the constructed CAR-T cells displayed comparable clinical efficacies to those of scFv. In addition, LCAR-B38M, constructed with bivalent nanobodies, indicated the feasibility of developing and manufacturing bi-specific/valent CARs.

Author Contributions: The review article is organized and written by C.B., J.Z. and X.-H.W. The clinical trial and data collection have been carried out by Q.G., L.-1.L., L.H. and B.Z. The manufacturing of CAR-T cells has been performed by Y.D., Z.S., R.Z. and J.Z. Finally, all authors have read and agreed the published version of the manuscript.

Funding: This research was funded by the Pregene and the clinical study was funded by grants from Henan Medical Science and Technology Foundation (grant number 2018020484; SBGJ2018085); Henan Provincial Scientific and Technological Project (grant number 162300410095).

Institutional Review Board Statement: The clinical study was approved by the institutional review boards of the Henan Cancer Hospital.

Informed Consent Statement: Informed consent was obtained from all patients.

Data Availability Statement: Patient-related data not included in the paper were generated as part of a clinical trial and may be subject to patient confidentiality. The datasets used and/or analyzed during the current study are available from the corresponding author on reasonable request.

Acknowledgments: We thank S. Muyldermans for his fruitful discussions on manuscript organization and scientific suggestions.

Conflicts of Interest: Chaolemeng Bao, Bingxiang Zhang, Yijin Ding, Zongpei Song, Ruining Zhang, Jishuai Zhang, and Xian-Hui Wu have received supports from Shenzhen Pregene Biopharma Co., Ltd. All the other authors declare no conflict of interest.

\section{References}

1. Yu, J.X.; Hubbard-Lucey, V.M.; Tang, J. Immuno-oncology drug development goes global. Nat. Rev. Drug Discov. 2019, 18, 899-900. [CrossRef]

2. Yu, J.X.; Hubbard-Lucey, V.M.; Tang, J. The global pipeline of cell therapies for cancer. Nat. Rev. Drug Discov. 2019, 18, 821-822. [CrossRef]

3. Yu, J.X.; Upadhaya, S.; Tatake, R.; Barkalow, F.; Hubbard-Lucey, V.M. Cancer cell therapies: The clinical trial landscape. Nat. Rev. Drug Discov. 2020, 19, 583-584. [CrossRef] [PubMed]

4. Geyer, M.B. First CAR to Pass the Road Test: Tisagenlecleucel's Drive to FDA Approval. Clin. Cancer Res. 2019, $25,1133-1135$. [CrossRef] [PubMed]

5. Bouchkouj, N.; Kasamon, Y.L.; de Claro, R.A.; George, B.; Lin, X.; Lee, S.; Blumenthal, G.M.; Bryan, W.; McKee, A.E.; Pazdur, R. FDA Approval Summary: Axicabtagene Ciloleucel for Relapsed or Refractory Large B-cell Lymphoma. Clin. Cancer Res. 2019, 25, 1702-1708. [CrossRef]

6. Wang, M.; Munoz, J.; Goy, A.; Locke, F.L.; Jacobson, C.A.; Hill, B.T.; Timmerman, J.M.; Holmes, H.; Jaglowski, S.; Flinn, I.W.; et al. KTE-X19 CAR T-Cell Therapy in Relapsed or Refractory Mantle-Cell Lymphoma. N. Engl. J. Med. 2020, 382, 1331-1342. [CrossRef] [PubMed]

7. Rothstein, T.L.; Mage, M.; Jones, G.; McHugh, L.L. Cytotoxic T lymphocyte sequential killing of immobilized allogeneic tumor target cells measured by time-lapse microcinematography. J. Immunol. 1978, 121, 1652-1656. [PubMed]

8. Martz, E. Multiple target cell killing by the cytolytic T lymphocyte and the mechanism of cytotoxicity. Transplantation 1976, 21, 5-11. [CrossRef]

9. Topalian, S.L.; Muul, L.M.; Solomon, D.; Rosenberg, S.A. Expansion of human tumor infiltrating lymphocytes for use in immunotherapy trials. J. Immunol. Methods 1987, 102, 127-141. [CrossRef]

10. Topalian, S.L.; Solomon, D.; Avis, F.P.; Chang, A.E.; Freerksen, D.L.; Linehan, W.M.; Lotze, M.T.; Robertson, C.N.; Seipp, C.A.; Simon, P. Immunotherapy of patients with advanced cancer using tumor-infiltrating lymphocytes and recombinant interleukin-2: A pilot study. J. Clin. Oncol. 1988, 6, 839-853. [CrossRef] [PubMed]

11. Rosenberg, S.A.; Packard, B.S.; Aebersold, P.M.; Solomon, D.; Topalian, S.L.; Toy, S.T.; Simon, P.; Lotze, M.T.; Yang, J.C.-H.; Seipp, C.A.; et al. Use of Tumor-Infiltrating Lymphocytes and Interleukin-2 in the Immunotherapy of Patients with Metastatic Melanoma. N. Engl. J. Med. 1988, 319, 1676-1680. [CrossRef] [PubMed]

12. Yamamoto, T.N.; Kishton, R.J.; Restifo, N.P. Developing neoantigen-targeted T cell-based treatments for solid tumors. Nat. Med. 2019, 25, 1488-1499. [CrossRef] [PubMed] 
13. Garber, K. Driving T-cell immunotherapy to solid tumors. Nat. Biotechnol. 2018, 36, 215-219. [CrossRef]

14. Gross, G.; Waks, T.; Eshhar, Z. Expression of immunoglobulin-T-cell receptor chimeric molecules as functional receptors with antibody-type specificity. Proc. Natl. Acad. Sci. USA 1989, 86, 10024-10028. [CrossRef] [PubMed]

15. Eshhar, Z.; Waks, T.; Gross, G.; Schindler, D.G. Specific activation and targeting of cytotoxic lymphocytes through chimeric single chains consisting of antibody-binding domains and the gamma or zeta subunits of the immunoglobulin and T-cell receptors. Proc. Natl. Acad. Sci. USA 1993, 90, 720-724. [CrossRef] [PubMed]

16. Tokarew, N.; Ogonek, J.; Endres, S.; von Bergwelt-Baildon, M.; Kobold, S. Teaching an old dog new tricks: Next-generation CAR T cells. Br. J. Cancer 2019, 120, 26-37. [CrossRef] [PubMed]

17. Hong, M.; Clubb, J.D.; Chen, Y.Y. Engineering CAR-T Cells for Next-Generation Cancer Therapy. Cancer Cell 2020, 38, 473-488. [CrossRef] [PubMed]

18. Eshhar, Z.; Waks, T.; Gross, G. The Emergence of T-Bodies/CAR T Cells. Cancer J. 2014, 20, 123-126. [CrossRef] [PubMed]

19. Gimmi, C.D.; Freeman, G.J.; Gribben, J.G.; Gray, G.; Nadler, L.M. Human T-cell clonal anergy is induced by antigen presentation in the absence of B7 costimulation. Proc. Natl. Acad. Sci. USA 1993, 90, 6586-6590. [CrossRef] [PubMed]

20. Finney, H.M.; Lawson, A.D.; Bebbington, C.R.; Weir, A.N. Chimeric receptors providing both primary and costimulatory signaling in T cells from a single gene product. J. Immunol. 1998, 161, 2791-2797. [PubMed]

21. Imai, C.; Mihara, K.; Andreansky, M.; Nicholson, I.C.; Pui, C.-H.; Geiger, T.L.; Campana, D. Chimeric receptors with 4-1BB signaling capacity provoke potent cytotoxicity against acute lymphoblastic leukemia. Leukemia 2004, 18, 676-684. [CrossRef] [PubMed]

22. Finney, H.M.; Akbar, A.N.; Lawson, A.D.G. Activation of Resting Human Primary T Cells with Chimeric Receptors: Costimulation from CD28, Inducible Costimulator, CD134, and CD137 in Series with Signals from the TCR $\zeta$ Chain. J. Immunol. 2004, 172, 104-113. [CrossRef] [PubMed]

23. Hombach, A.; Sent, D.; Schneider, C.; Heuser, C.; Koch, D.; Pohl, C.; Seliger, B.; Abken, H. T-cell activation by recombinant receptors: CD28 costimulation is required for interleukin 2 secretion and receptor-mediated T-cell proliferation but does not affect receptor-mediated target cell lysis. Cancer Res. 2001, 61, 1976-1982. [PubMed]

24. Kowolik, C.M.; Topp, M.S.; Gonzalez, S.; Pfeiffer, T.; Olivares, S.; Gonzalez, N.; Smith, D.D.; Forman, S.J.; Jensen, M.C.; Cooper, L.J. CD28 Costimulation Provided through a CD19-Specific Chimeric Antigen Receptor Enhances In vivo Persistence and Antitumor Efficacy of Adoptively Transferred T Cells. Cancer Res. 2006, 66, 10995-11004. [CrossRef] [PubMed]

25. Milone, M.C.; Fish, J.D.; Carpenito, C.; Carroll, R.G.; Binder, G.K.; Teachey, D.; Samanta, M.; Lakhal, M.; Gloss, B.; DanetDesnoyers, G.; et al. Chimeric Receptors Containing CD137 Signal Transduction Domains Mediate Enhanced Survival of T Cells and Increased Antileukemic Efficacy In Vivo. Mol. Ther. 2009, 17, 1453-1464. [CrossRef] [PubMed]

26. Pulè, M.A.; Straathof, K.C.; Dotti, G.; Heslop, H.E.; Rooney, C.M.; Brenner, M.K. A chimeric T cell antigen receptor that augments cytokine release and supports clonal expansion of primary human T cells. Mol. Ther. 2005, 12, 933-941. [CrossRef] [PubMed]

27. Enblad, G.; Karlsson, H.; Gammelgård, G.; Wenthe, J.; Lövgren, T.; Amini, R.M.; Wikstrom, K.I.; Essand, M.; Savoldo, B.; Hallböök, H.; et al. A Phase I/IIa Trial Using CD19-Targeted Third-Generation CAR T Cells for Lymphoma and Leukemia. Clin. Cancer Res. 2018, 24, 6185-6194. [CrossRef] [PubMed]

28. Ramos, C.A.; Rouce, R.; Robertson, C.S.; Reyna, A.; Narala, N.; Vyas, G.; Mehta, B.; Zhang, H.; Dakhova, O.; Carrum, G.; et al. In Vivo Fate and Activity of Second- versus Third-Generation CD19-Specific CAR-T Cells in B Cell Non-Hodgkin's Lymphomas Mol. Ther. 2018, 26, 2727-2737. [CrossRef] [PubMed]

29. Wagner, J.; Wickman, E.; Derenzo, C.; Gottschalk, S. CAR T Cell Therapy for Solid Tumors: Bright Future or Dark Reality? Mol. Ther. 2020, 28, 2320-2339. [CrossRef]

30. Martinez, M.; Moon, E.K. CAR T Cells for Solid Tumors: New Strategies for Finding, Infiltrating, and Surviving in the Tumor Microenvironment. Front. Immunol. 2019, 10, 128. [CrossRef] [PubMed]

31. Chmielewski, M.; Abken, H. TRUCKs: The fourth generation of CARs. Expert Opin. Biol. Ther. 2015, 15, 1145-1154. [CrossRef] [PubMed]

32. Cohen, J. Clinical Trials: IL-12 Deaths: Explanation and a Puzzle. Science 1995, 270, 908. [CrossRef] [PubMed]

33. Berraondo, P.; Etxeberria, I.; Ponz-Sarvise, M.; Melero, I. Revisiting Interleukin-12 as a Cancer Immunotherapy Agent. Clin. Cancer Res. 2018, 24, 2716-2718. [CrossRef] [PubMed]

34. Nguyen, K.G.; Vrabel, M.R.; Mantooth, S.M.; Hopkins, J.J.; Wagner, E.S.; Gabaldon, T.A.; Zaharoff, D.A. Localized Interleukin-12 for Cancer Immunotherapy. Front. Immunol. 2020, 11, 575597. [CrossRef] [PubMed]

35. Yeku, O.O.; Purdon, T.J.; Koneru, M.; Spriggs, D.; Brentjens, R.J. Armored CAR T cells enhance antitumor efficacy and overcome the tumor microenvironment. Sci. Rep. 2017, 7, 1-14. [CrossRef] [PubMed]

36. Liu, Y.; Di, S.; Shi, B.; Zhang, H.; Wang, Y.; Wu, X.; Luo, H.; Wang, H.; Li, Z.; Jiang, H. Armored Inducible Expression of IL-12 Enhances Antitumor Activity of Glypican-3-Targeted Chimeric Antigen Receptor-Engineered T Cells in Hepatocellular Carcinoma. J. Immunol. 2019, 203, 198-207. [CrossRef]

37. Alizadeh, D.; Wong, R.A.; Yang, X.; Wang, D.; Pecoraro, J.R.; Kuo, C.-F.; Aguilar, B.; Qi, Y.; Ann, D.K.; Starr, R.; et al. IL15 Enhances CAR-T Cell Antitumor Activity by Reducing mTORC1 Activity and Preserving Their Stem Cell Memory Phenotype. Cancer Immunol. Res. 2019, 7, 759-772. [CrossRef]

38. Hu, B.; Ren, J.; Luo, Y.; Keith, B.; Young, R.M.; Scholler, J.; Zhao, Y.; June, C.H. Augmentation of Antitumor Immunity by Human and Mouse CAR T Cells Secreting IL-18. Cell Rep. 2017, 20, 3025-3033. [CrossRef] [PubMed] 
39. Avanzi, M.P.; Yeku, O.; Li, X.; Wijewarnasuriya, D.P.; van Leeuwen, D.G.; Cheung, K.; Park, H.; Purdon, T.J.; Daniyan, A.F.; Spitzer, M.H.; et al. Engineered Tumor-Targeted T Cells Mediate Enhanced Anti-Tumor Efficacy Both Directly and through Activation of the Endogenous Immune System. Cell Rep. 2018, 23, 2130-2141. [CrossRef] [PubMed]

40. Morgan, R.A.; Dudley, M.E.; Wunderlich, J.R.; Hughes, M.S.; Yang, J.C.; Sherry, R.M.; Royal, R.E.; Topalian, S.L.; Kammula, U.S.; Restifo, N.P.; et al. Cancer Regression in Patients After Transfer of Genetically Engineered Lymphocytes. Science 2006, 314, 126-129. [CrossRef] [PubMed]

41. Strohl, W.R.; Naso, M. Bispecific T-Cell Redirection versus Chimeric Antigen Receptor (CAR)-T Cells as Approaches to Kill Cancer Cells. Antibodies 2019, 8, 41. [CrossRef] [PubMed]

42. Nieba, L.; Honegger, A.; Krebber, C.; Pluckthun, A. Disrupting the hydrophobic patches at the antibody variable/constant domain interface: Improved in vivo folding and physical characterization of an engineered scFv fragment. Protein Eng. Des. Sel. 1997, 10, 435-444. [CrossRef] [PubMed]

43. Völkel, T.; Korn, T.; Bach, M.; Müller, R.; Kontermann, R.E. Optimized linker sequences for the expression of monomeric and dimeric bispecific single-chain diabodies. Protein Eng. 2001, 14, 815-823. [CrossRef] [PubMed]

44. Gorovits, B.; Koren, E. Immunogenicity of Chimeric Antigen Receptor T-Cell Therapeutics. BioDrugs 2019, 33, 275-284. [CrossRef] [PubMed]

45. Shah, N.N.; Fry, T.J. Mechanisms of resistance to CAR T cell therapy. Nat. Rev. Clin. Oncol. 2019, 16, 1-385. [CrossRef] [PubMed]

46. Long, A.H.; Haso, W.M.; Shern, J.F.; Wanhainen, K.M.; Murgai, M.; Ingaramo, M.; Ferguson-Smith, A.C.; Walker, A.J.; Kohler, M.E.; Venkateshwara, V.R.; et al. 4-1BB costimulation ameliorates T cell exhaustion induced by tonic signaling of chimeric antigen receptors. Nat. Med. 2015, 21, 581-590. [CrossRef]

47. Sun, W.; Xie, J.; Lin, H.; Mi, S.; Li, Z.; Hua, F.; Hu, Z.-W. A combined strategy improves the solubility of aggregation-prone single-chain variable fragment antibodies. Protein Expr. Purif. 2012, 83, 21-29. [CrossRef] [PubMed]

48. Hegde, M.; Mukherjee, M.; Grada, Z.; Pignata, A.; Landi, D.; Navai, S.A.; Wakefield, A.; Fousek, K.; Bielamowicz, K.; Chow, K.K.; et al. Tandem CAR T cells targeting HER2 and IL13R $\alpha 2$ mitigate tumor antigen escape. J. Clin. Investig. 2016, 126, 3036-3052. [CrossRef]

49. Kumar, M.; Keller, B.; Makalou, N.; Sutton, R.E. Systematic Determination of the Packaging Limit of Lentiviral Vectors. Hum. Gene Ther. 2001, 12, 1893-1905. [CrossRef] [PubMed]

50. Bos, T.J.; de Bruyne, E.; van Lint, S.; Heirman, C.; Vanderkerken, K. Large double copy vectors are functional but show a size-dependent decline in transduction efficiency. J. Biotechnol. 2010, 150, 37-40. [CrossRef]

51. Al-Yacoub, N.; Romanowska, M.; Haritonova, N.; Foerster, J. Optimized production and concentration of lentiviral vectors containing large inserts. J. Gene Med. 2007, 9, 579-584. [CrossRef] [PubMed]

52. Gil, D.; Schrum, A.G. Strategies to stabilize compact folding and minimize aggregation of antibody-based fragments. Adv. Biosci. Biotechnol. 2013, 4, 73-84. [CrossRef] [PubMed]

53. Jäger, M.; Plückthun, A. Domain interactions in antibody Fv and scFv fragments: Effects on unfolding kinetics and equilibria. FEBS Lett. 1999, 462, 307-312. [CrossRef]

54. Jayaraman, J.; Mellody, M.P.; Hou, A.J.; Desai, R.P.; Fung, A.W.; Pham, A.H.T.; Chen, Y.Y.; Zhao, W. CAR-T design: Elements and their synergistic function. EBioMedicine 2020, 58, 102931. [CrossRef] [PubMed]

55. Hamers-Casterman, C.; Atarhouch, T.; Muyldermans, S.; Robinson, G.; Hammers, C.; Songa, E.B.; Bendahman, N.; Hammers, R. Naturally occurring antibodies devoid of light chains. Nature 1993, 363, 446-448. [CrossRef] [PubMed]

56. Muyldermans, S. Nanobodies: Natural Single-Domain Antibodies. Annu. Rev. Biochem. 2013, 82, 775-797. [CrossRef] [PubMed]

57. Greenberg, A.S.; Avila, D.; Hughes, M.; Hughes, A.; McKinney, E.C.; Flajnik, M.F. A new antigen receptor gene family that undergoes rearrangement and extensive somatic diversification in sharks. Nat. Cell Biol. 1995, 374, 168-173. [CrossRef] [PubMed]

58. Vu, K.B.; Ghahroudi, M.A.; Wyns, L.; Muyldermans, S. Comparison of llama VH sequences from conventional and heavy chain antibodies. Mol. Immunol. 1997, 34, 1121-1131. [CrossRef]

59. Bannas, P.; Hambach, J.; Koch-Nolte, F. Nanobodies and Nanobody-Based Human Heavy Chain Antibodies as Antitumor Therapeutics. Front. Immunol. 2017, 8, 1603. [CrossRef] [PubMed]

60. Gulati, S.; Jin, H.; Masuho, I.; Orban, T.; Cai, Y.; Pardon, E.; Martemyanov, K.A.; Kiser, P.D.; Stewart, P.L.; Ford, C.P.; et al. Targeting $G$ protein-coupled receptor signaling at the $G$ protein level with a selective nanobody inhibitor. Nat. Commun. 2018, 9 , 1-15. [CrossRef] [PubMed]

61. Vincke, C.; Loris, R.; Saerens, D.; Martinez-Rodriguez, S.; Muyldermans, S.; Conrath, K. General Strategy to Humanize a Camelid Single-domain Antibody and Identification of a Universal Humanized Nanobody Scaffold. J. Biol. Chem. 2009, 284, 3273-3284. [CrossRef] [PubMed]

62. Jovčevska, I.; Muyldermans, S. The Therapeutic Potential of Nanobodies. BioDrugs 2020, 34, 11-26. [CrossRef] [PubMed]

63. Chanier, T.; Chames, P. Nanobody Engineering: Toward Next Generation Immunotherapies and Immunoimaging of Cancer. Antibodies 2019, 8, 13. [CrossRef] [PubMed]

64. Bakhtiari, S.H.A.; Rahbarizadeh, F.; Hasannia, S.; Ahmadvand, D.; Iri-Sofla, F.J.; Rasaee, M.J. Anti-MUC1 Nanobody Can Redirect T-Body Cytotoxic Effector Function. Hybridoma 2009, 28, 85-92. [CrossRef]

65. Iri-Sofla, F.J.; Rahbarizadeh, F.; Ahmadvand, D.; Rasaee, M.J. Nanobody-based chimeric receptor gene integration in Jurkat cells mediated by PhiC31 integrase. Exp. Cell Res. 2011, 317, 2630-2641. [CrossRef] [PubMed] 
66. Khaleghi, S.; Rahbarizadeh, F.; Ahmadvand, D.; Rasaee, M.J.; Pognonec, P. A caspase 8-based suicide switch induces apoptosis in nanobody-directed chimeric receptor expressing T cells. Int. J. Hematol. 2012, 95, 434-444. [CrossRef] [PubMed]

67. Sharifzadeh, Z.; Rahbarizadeh, F.; Shokrgozar, M.A.; Ahmadvand, D.; Mahboudi, F.; Jamnani, F.R.; Moghimi, S.M. Genetically engineered $\mathrm{T}$ cells bearing chimeric nanoconstructed receptors harboring TAG-72-specific camelid single domain antibodies as targeting agents. Cancer Lett. 2013, 334, 237-244. [CrossRef] [PubMed]

68. Jamnani, F.R.; Rahbarizadeh, F.; Shokrgozar, M.A.; Mahboudi, F.; Ahmadvand, D.; Sharifzadeh, Z.; Parhamifar, L.; Moghimi, S.M. T cells expressing VHH-directed oligoclonal chimeric HER2 antigen receptors: Towards tumor-directed oligoclonal T cell therapy. Biochim. Biophys. Acta Gen. Subj. 2014, 1840, 378-386. [CrossRef] [PubMed]

69. Hajari Taheri, F.; Hassani, M.; Sharifzadeh, Z.; Behdani, M.; Arashkia, A.; Abolhassani, M. T cell engineered with a novel nanobody-based chimeric antigen receptor against VEGFR2 as a candidate for tumor immunotherapy. IUBMB Life 2019, 71, 1259-1267. [CrossRef]

70. Hassani, M.; Taheri, F.H.; Sharifzadeh, Z.; Arashkia, A.; Hadjati, J.; van Weerden, W.M.; Modarressi, M.H.; Abolhassani, M. Construction of a chimeric antigen receptor bearing a nanobody against prostate a specific membrane antigen in prostate cancer. J. Cell. Biochem. 2019, 120, 10787-10795. [CrossRef] [PubMed]

71. Li, N.; Fu, H.; Hewitt, S.M.; Dimitrov, D.S.; Ho, M. Therapeutically targeting glypican-2 via single-domain antibody-based chimeric antigen receptors and immunotoxins in neuroblastoma. Proc. Natl. Acad. Sci. USA 2017, 114, E6623-E6631. [CrossRef] [PubMed]

72. Xie, Y.J.; Dougan, M.; Jailkhani, N.; Ingram, J.; Fang, T.; Kummer, L.; Momin, N.; Pishesha, N.; Rickelt, S.; Hynes, R.O.; et al. Nanobody-based CAR T cells that target the tumor microenvironment inhibit the growth of solid tumors in immunocompetent mice. Proc. Natl. Acad. Sci. USA 2019, 116, 7624-7631. [CrossRef] [PubMed]

73. An, N.; Hou, Y.N.; Zhang, Q.X.; Li, T.; Zhang, Q.L.; Fang, C.; Chen, H.; Lee, H.C.; Zhao, Y.J.; Du, X. Anti-Multiple Myeloma Activity of Nanobody-Based Anti-CD38 Chimeric Antigen Receptor T Cells. Mol. Pharm. 2018, 15, 4577-4588. [CrossRef]

74. Hambach, J.; Riecken, K.; Cichutek, S.; Schütze, K.; Albrecht, B.; Petry, K.; Röckendorf, J.L.; Baum, N.; Kröger, N.; Hansen, T.; et al. Targeting CD38-Expressing Multiple Myeloma and Burkitt Lymphoma Cells In Vitro with Nanobody-Based Chimeric Antigen Receptors (Nb-CARs). Cells 2020, 9, 321. [CrossRef] [PubMed]

75. Zhao, W.-H.; Liu, J.; Wang, B.-Y.; Chen, Y.-X.; Cao, X.-M.; Yang, Y.; Zhang, Y.-L.; Wang, F.-X.; Zhang, P.-Y.; Lei, B.; et al. A phase 1, open-label study of LCAR-B38M, a chimeric antigen receptor T cell therapy directed against B cell maturation antigen, in patients with relapsed or refractory multiple myeloma. J. Hematol. Oncol. 2018, 11, 141. [CrossRef] [PubMed]

76. Xu, J.; Chen, L.-J.; Yang, S.-S.; Sun, Y.; Wu, W.; Liu, Y.-F.; Zhuang, Y.; Zhang, W.; Weng, X.-Q.; Wu, J.; et al. Exploratory trial of a biepitopic CAR T-targeting B cell maturation antigen in relapsed/refractory multiple myeloma. Proc. Natl. Acad. Sci. USA 2019, 116, 9543-9551. [CrossRef] [PubMed]

77. Han, L.; Zhou, J.; Zhou, K.; Zhu, X.; Zhao, L.; Fang, B.; Yin, Q.; Wei, X.; Zhou, H.; Li, L.; et al. Safety and efficacy of CAR-T cell targeting BCMA in patients with multiple myeloma coinfected with chronic hepatitis B virus. J. Immunother. Cancer 2020, 8, e000927. [CrossRef] [PubMed]

78. De Munter, S.; van Parys, A.; Bral, L.; Ingels, J.; Goetgeluk, G.; Bonte, S.; Pille, M.; Billiet, L.; Weening, K.; Verhee, A.; et al. Rapid and Effective Generation of Nanobody Based CARs using PCR and Gibson Assembly. Int. J. Mol. Sci. 2020, 21, 883. [CrossRef] [PubMed]

79. Ishikawa, Y.; Tanaka, N.; Murakami, K.; Uchiyama, T.; Kumaki, S.; Tsuchiya, S.; Kugoh, H.; Oshimura, M.; Calos, M.P.; Sugamura, K. Phage phiC31 integrase-mediated genomic integration of the common cytokine receptor gamma chain in human T-cell lines. $J$. Gene Med. 2006, 8, 646-653. [CrossRef] [PubMed]

80. Mp, C. The $\varphi$ C31 Integrase System for Gene Therapy. Curr. Gene Ther. 2006, 6, 633-645. [CrossRef]

81. Goel, H.L.; Mercurio, A.M. VEGF targets the tumour cell. Nat. Rev. Cancer 2013, 13, 871-882. [CrossRef] [PubMed]

82. Khan, K.A.; Kerbel, R.S. Improving immunotherapy outcomes with anti-angiogenic treatments and vice versa. Nat. Rev. Clin. Oncol. 2018, 15, 310-324. [CrossRef] [PubMed]

83. Ntellas, P.; Mavroeidis, L.; Gkoura, S.; Gazouli, I.; Amylidi, A.-L.; Papadaki, A.; Zarkavelis, G.; Mauri, D.; Karpathiou, G.; Kolettas, E.; et al. Old Player-New Tricks: Non Angiogenic Effects of the VEGF/VEGFR Pathway in Cancer. Cancers 2020, 12, 3145. [CrossRef]

84. Chinnasamy, D.; Yu, Z.; Theoret, M.R.; Zhao, Y.; Shrimali, R.K.; Morgan, R.A.; Feldman, S.A.; Restifo, N.P.; Rosenberg, S.A. Gene therapy using genetically modified lymphocytes targeting VEGFR-2 inhibits the growth of vascularized syngenic tumors in mice. J. Clin. Investig. 2010, 120, 3953-3968. [CrossRef] [PubMed]

85. Lanitis, E.; Irving, M.; Coukos, G. Targeting the tumor vasculature to enhance T cell activity. Curr. Opin. Immunol. 2015, 33, 55-63. [CrossRef]

86. Behdani, M.; Zeinali, S.; Khanahmad, H.; Karimipour, M.; Asadzadeh, N.; Azadmanesh, K.; Khabiri, A.; Schoonooghe, S.; Anbouhi, M.H.; Hassanzadeh-Ghassabeh, G.; et al. Generation and characterization of a functional Nanobody against the vascular endothelial growth factor receptor-2; angiogenesis cell receptor. Mol. Immunol. 2012, 50, 35-41. [CrossRef]

87. Chatalic, K.; Veldhoven-Zweistra, J.; Bolkestein, M.; Hoeben, S.; Koning, G.A.; Boerman, O.C.; de Jong, M.; van Weerden, W.M. A Novel 111In-Labeled Anti-Prostate-Specific Membrane Antigen Nanobody for Targeted SPECT/CT Imaging of Prostate Cancer. J. Nucl. Med. 2015, 56, 1094-1099. [CrossRef] 
88. Chen, W.; Zhu, Z.; Xiao, X.; Dimitrov, D.S. Construction of a Human Antibody Domain (VH) Library. Toxicity Assessment 2008, 525, 81-99. [CrossRef]

89. Ingram, J.R.; Dougan, M.; Rashidian, M.; Knoll, M.; Keliher, E.J.; Garrett, S.; Garforth, S.; Blomberg, O.S.; Espinosa, C.; Bhan, A.; et al. PD-L1 is an activation-independent marker of brown adipocytes. Nat. Commun. 2017, 8, 1-10. [CrossRef] [PubMed]

90. Ohaegbulam, K.C.; Assal, A.; Lazar-Molnar, E.; Yao, Y.; Zang, X. Human cancer immunotherapy with antibodies to the PD-1 and PD-L1 pathway. Trends Mol. Med. 2015, 21, 24-33. [CrossRef] [PubMed]

91. Lu, D.; Ni, Z.; Liu, X.; Feng, S.; Dong, X.; Shi, X.; Zhai, J.; Mai, S.; Jiang, J.; Wang, Z.; et al. Beyond T Cells: Understanding the Role of PD-1/PD-L1 in Tumor-Associated Macrophages. J. Immunol. Res. 2019, 2019, 1-7. [CrossRef]

92. Tseng, Y.-C.; Ho, H.-L.; Lai, C.-R.; Luo, Y.-H.; Whang-Peng, J.; Lin, Y.-H.; Chou, T.-Y.; Chen, Y.-M. PD-L1 Expression of Tumor Cells, Macrophages, and Immune Cells in Non-Small Cell Lung Cancer Patients with Malignant Pleural Effusion. J. Thorac. Oncol. 2018, 13, 447-453. [CrossRef] [PubMed]

93. Castellani, P.; Viale, G.; Dorcaratto, A.; Nicolo, G.; Kaczmarek, J.; Querze, G.; Zardi, L. The fibronectin isoform containing the ed-b oncofetal domain: A marker of angiogenesis. Int. J. Cancer 1994, 59, 612-618. [CrossRef] [PubMed]

94. Jailkhani, N.; Ingram, J.R.; Rashidian, M.; Rickelt, S.; Tian, C.; Mak, H.; Jiang, Z.; Ploegh, H.L.; Hynes, R.O. Noninvasive imaging of tumor progression, metastasis, and fibrosis using a nanobody targeting the extracellular matrix. Proc. Natl. Acad. Sci. USA 2019, 116, 14181-14190. [CrossRef] [PubMed]

95. Malavasi, F.; Deaglio, S.; Funaro, A.; Ferrero, E.; Horenstein, A.L.; Ortolan, E.; Vaisitti, T.; Aydin, S. Evolution and Function of the ADP Ribosyl Cyclase/CD38 Gene Family in Physiology and Pathology. Physiol. Rev. 2008, 88, 841-886. [CrossRef] [PubMed]

96. Van de Donk, N.W.C.J.; Richardson, P.G.; Malavasi, F. CD38 antibodies in multiple myeloma: Back to the future. Blood 2018, 131, 13-29. [CrossRef] [PubMed]

97. Mikhael, J.; Richardson, P.; Usmani, S.Z.; Raje, N.; Bensinger, W.; Karanes, C.; Campana, F.; Kanagavel, D.; Dubin, F.; Liu, Q.; et al. A phase $1 \mathrm{~b}$ study of isatuximab plus pomalidomide/dexamethasone in relapsed/refractory multiple myeloma. Blood 2019, 134, 123-133. [CrossRef] [PubMed]

98. Li, T.; Qi, S.; Unger, M.; Hou, Y.N.; Deng, Q.W.; Liu, J.; Lam, C.M.C.; Wang, X.W.; Xin, D.; Zhang, P.; et al. Immuno-targeting the multifunctional CD38 using nanobody. Sci. Rep. 2016, 6, 27055. [CrossRef] [PubMed]

99. Fumey, W.; Koenigsdorf, J.; Kunick, V.; Menzel, S.; Schütze, K.; Unger, M.; Schriewer, L.; Haag, F.; Adam, G.; Oberle, A.; et al. Nanobodies effectively modulate the enzymatic activity of CD38 and allow specific imaging of CD38+ tumors in mouse models in vivo. Sci. Rep. 2017, 7, 1-13. [CrossRef] [PubMed]

100. Raje, N.; Berdeja, J.; Lin, Y.; Siegel, D.; Jagannath, S.; Madduri, D.; Liedtke, M.; Rosenblatt, J.; Maus, M.V.; Turka, A.; et al. Anti-BCMA CAR T-Cell Therapy bb2121 in Relapsed or Refractory Multiple Myeloma. N. Engl. J. Med. 2019, 380, $1726-1737$. [CrossRef]

101. Rahbarizadeh, F.; Rasaee, M.J.; Moghadam, M.F.; Allameh, A.; Sadroddiny, E. Production of Novel Recombinant Single-Domain Antibodies against Tandem Repeat Region of MUC1 Mucin. Hybrid. Hybridomics 2004, 23, 151-159. [CrossRef]

102. Carlotti, F.; Zaldumbide, A.; Martin, P.; Boulukos, K.E.; Hoeben, R.C.; Pognonec, P. Development of an inducible suicide gene system based on human caspase 8. Cancer Gene Ther. 2005, 12, 627-639. [CrossRef] [PubMed]

103. Albert, S.; Arndt, C.; Feldmann, A.; Bergmann, R.; Bachmann, D.; Koristka, S.; Ludwig, F.; Ziller-Walter, P.; Kegler, A.; Gärtner, S.; et al. A novel nanobody-based target module for retargeting of T lymphocytes to EGFR-expressing cancer cells via the modular UniCAR platform. OncoImmunology 2017, 6, e1287246. [CrossRef] [PubMed]

104. Albert, S.; Arndt, C.; Koristka, S.; Berndt, N.; Bergmann, R.; Feldmann, A.; Schmitz, M.; Pietzsch, J.; Steinbach, J.; Bachmann, M. From mono- to bivalent: Improving theranostic properties of target modules for redirection of UniCAR T cells against EGFR-expressing tumor cells in vitro and in vivo. Oncotarget 2018, 9, 25597-25616. [CrossRef] [PubMed]

105. De Munter, S.; Ingels, J.; Goetgeluk, G.; Bonte, S.; Pille, M.; Weening, K.; Kerre, T.; Abken, H.; Vandekerckhove, B. Nanobody Based Dual Specific CARs. Int. J. Mol. Sci. 2018, 19, 403. [CrossRef]

106. Xie, Y.J.; Dougan, M.; Ingram, J.R.; Pishesha, N.; Fang, T.; Momin, N.; Ploegh, H.L. Improved Antitumor Efficacy of Chimeric Antigen Receptor T Cells that Secrete Single-Domain Antibody Fragments. Cancer Immunol. Res. 2020, 8, 518-529. [CrossRef]

107. Cartellieri, M.; Feldmann, A.; Koristka, S.; Arndt, C.; Loff, S.; Ehninger, A.; von Bonin, M.; Bejestani, E.P.; Bachmann, M.P. Switching CAR T cells on and off: A novel modular platform for retargeting of T cells to AML blasts. Blood Cancer J. 2016, 6, e458. [CrossRef] [PubMed]

108. Han, L.; Gao, Q.; Zhou, K.; Zhou, J.; Fang, B.; Zhang, J.; Li, H.; Song, Y. The phase I clinical study of CART targeting BCMA with humanized alpaca-derived single-domain antibody as antigen recognition domain. J. Clin. Oncol. 2019, 37, 2535. [CrossRef]

109. Wang, B.-Y.; Zhao, W.-H.; Liu, J.; Chen, Y.-X.; Cao, X.-M.; Yang, Y.; Zhang, Y.-L.; Wang, F.-X.; Zhang, P.-Y.; Lei, B.; et al. Long-Term Follow-up of a Phase 1, First-in-Human Open-Label Study of LCAR-B38M, a Structurally Differentiated Chimeric Antigen Receptor T (CAR-T) Cell Therapy Targeting B-Cell Maturation Antigen (BCMA), in Patients (pts) with Relapsed/Refractory Multiple Myeloma (RRMM). Blood 2019, 134, 579. [CrossRef]

110. Madduri, D.; Berdeja, J.G.; Usmani, M.S.Z.; Jakubowiak, A.; Agha, M.; Cohen, A.D.; Stewart, M.A.K.; Hari, M.P.; Htut, M.; O'Donnell, E.; et al. CARTITUDE-1: Phase 1b/2 Study of Ciltacabtagene Autoleucel, a B-Cell Maturation Antigen-Directed Chimeric Antigen Receptor T Cell Therapy, in Relapsed/Refractory Multiple Myeloma. Blood 2020, 136, 22-25. [CrossRef]

111. Bonifant, C.L.; Jackson, H.J.; Brentjens, R.J.; Curran, K.J. Toxicity and management in CAR T-cell therapy. Mol. Ther. Oncolytics 2016, 3, 16011. [CrossRef] [PubMed] 
112. Yáñez, L.; Sánchez-Escamilla, M.; Perales, M.-A. CAR T Cell Toxicity: Current Management and Future Directions. HemaSphere 2019, 3, e186. [CrossRef] [PubMed]

113. Siegler, E.L.; Kenderian, S.S. Neurotoxicity and Cytokine Release Syndrome After Chimeric Antigen Receptor T Cell Therapy: Insights into Mechanisms and Novel Therapies. Front. Immunol. 2020, 11, 1973. [CrossRef] [PubMed] 